JDQS

30,1

\section{8}

Received 12 July 2021

Revised 4 October 2021

9 November 2021

Accepted 9 November 2021

\title{
Earnings quality, foreign investor and dividends
}

\author{
Jong Hwa Lee \\ Department of Finance, Dong-A University, Busan, Republic of Korea
}

\begin{abstract}
This study discovers the relation between corporate governance factors and earnings quality and finds that increases in dividends and foreign ownership deter earnings management. The author shows that dividend increases and foreign ownership enhance earnings quality, but they appear to be substitutes in that role. In other words, as foreign ownership increases, the influence of dividends in increasing earnings quality decreases. Improving transparency through dividend increases and monitoring by foreign institutional investors are substitutes in preventing earnings management.
\end{abstract}

Keywords Earnings quality, Earnings management, Dividends, Foreign investor, Monitoring effect Paper type Research paper

\section{Introduction}

This study investigates how earnings quality is improved by the interaction between foreign ownership and dividend payout policies. Corporate insiders who manage and operate a firm have opportunities and incentives to use corporate assets for their private benefits instead of maximizing firm value for the shareholders. While doing so, management may tamper with earnings by exaggerating performance in the income statement or concealing any unfavorable news. Previous studies argue that institutional ownership enhances corporate governance (Chen et al., 2007; Ferreira and Matos, 2008; Lel, 2019). Most of the foreign investors are institutions that have global experience and are independent of the firm management. They can actively monitor and deter any actions by the managers that hinder firm growth and disseminate strong corporate governance. Previous studies with multinational data have observed the impact of foreign ownership and dividends on decreasing earnings manipulation by insiders (He et al., 2017; Lel, 2019). Figure 1 shows how a measure of earnings management decreases as foreign ownership increases. Foreign investors help actively monitor corporate governance and prevent any foul plays.

Another set of evidence finds that dividends help restrain suboptimal behaviors of managers and deter earnings manipulation for private benefits. In addition, the role of dividends is to relieve information asymmetry between insiders and outsiders improving transparency. Payout policies, especially dividend increases, can attenuate mismanagements, such as manipulating earnings. Ham et al. (2020) show that dividend increase conveys information about future earnings. The decision to increase dividends is deeply from the managers' confidence that the firm performance will improve. Firms with such promising futures have better corporate governance and thus should manipulate

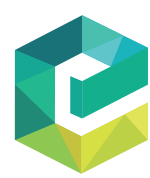

Journal of Derivatives and Quantitative Studies: 선물연구 Vol. 30 No. 1, 2022 pp. $58-72$

Emerald Publishing Limited e-ISSN: $2713-6647$

p-ISSN: $1229-988 \mathrm{X}$

DOI 10.1108/JDQS-07-2021-0018
JEL Classification - G30, G35

(C) Jong Hwa Lee. Published in Journal of Derivatives and Quantitative Studies: 선물연구. Published by Emerald Publishing Limited. This article is published under the Creative Commons Attribution (CC BY 4.0) licence. Anyone may reproduce, distribute, translate and create derivative works of this article (for both commercial and non-commercial purposes), subject to full attribution to the original publication and authors. The full terms of this licence maybe seen at http://creativecommons.org/licences/by/4.0/ legalcode.

This work was supported by the Dong-A University research fund.

This research is developed from the second chapter of my Ph.D. dissertation. 


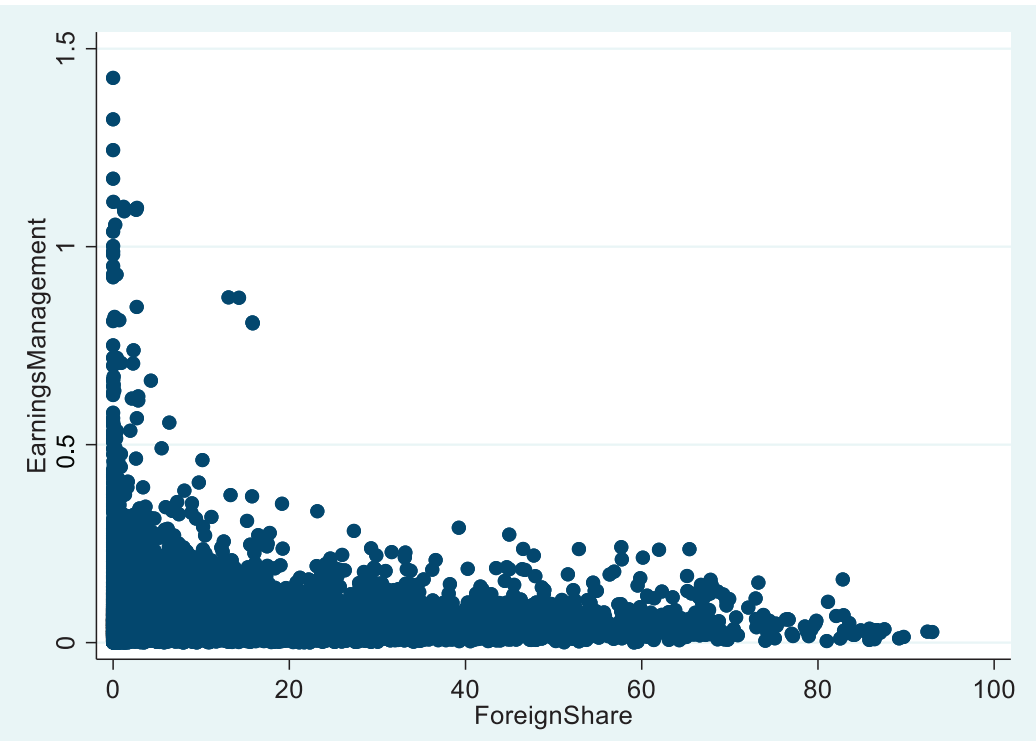

Note(s): This figure shows the scatterplot of foreign shares and earnings management.

Earnings management is measured using the method of Francis et al. (2005) and Dechow and Dichev (2002). The measure of earnings management is greater when earning is more volatile and deviates more from the expected value. This figure shows that the quality of information conveyed by earnings improves as foreign ownership share increases
Corporate governance factors

Figure 1.

Scatterplot of foreign share and earnings management

earnings less. Not only is the payout status important, but changes in dividends are also noteworthy.

This study discovers that the nonlinear relationship between dividends and earnings management is explained by the monitoring of foreign investors. The impact of dividends on earnings quality differs by firm ownership structure, and I provide evidence that foreign ownership can be a substitute for deterring management misbehavior. Dividend increases and foreign ownership act as substitutes in improving earnings quality where an increase in one decreases the impact of another. This relation is discovered using Korean firms listed in Korean composite stock prices indexes (KOSPI) and Korea association of securities dealers automated quotation (KOSDAQ). South Korea is a natural place to examine such interactions because Korea is still an emerging financial market with active foreign investments. Lel (2019) and He et al. (2017) suggest that emerging countries benefit from foreign investors monitoring firm managers to improve earnings quality.

Results are shown using univariate analysis similar to that in Dichev and Tang (2009). Additionally, fixed-effect panel regressions show how foreign ownership and dividend policies interactively reduce earnings management. I find that dividend changes help restrain earnings management with statistical significance regardless of foreign ownership structure. However, the impact of dividends in reducing agency costs and improving earnings quality decreases as foreign investor ownership increases. This finding indicates that dividends and foreign ownership are substitutes in deterring earnings management. 
JDQS 30,1

The rest of this paper is organized as follows: Section 2 reviews earnings quality. Section 3 describes the data and explains the methodology. Section 4 presents the results and Section 5 concludes.

\section{Overview of earnings quality}

\subsection{Measuring earnings management}

Earnings quality represents how well the reported earnings on the financial statements reflect true performances and fundamental value. Reported earnings can have favorable properties, such as persistence, smoothness, timeliness and target achieving that indicate positive performance. However, earnings manipulation activities cause reported earnings to deviate from fundamentals so that managers could take advantage of inside information and use the reports for their private benefits. This behavior is known as earnings management. Studies have constructed a measure to identify earnings management and analyzed how such actions affect firm performance and value.

Accounting and corporate finance literature reviews the significance of accruals in representing earnings management and how it relates to earnings persistence (Dechow et al., 2010). Studies have developed methods to quantify the quality of information that comes with earnings in the accounting book using accruals. Measures of accruals include total accruals, the absolute value of accruals, estimated errors when regressed on key factors of accruals and standard deviation of residuals from regressions to represent abnormality of accruals. These different measures have their own pros and cons which are reviewed by Dechow et al. (2010).

The idea is that earnings come from two components, cash flow and accruals. This property suggests that accruals have a part in explaining earnings persistence throughout time. However, calculating accruals is more difficult than it seems. Especially before the statement of cash flows was mandated under the generally accepted accounting principles (GAAP), accruals had a different implication than those currently used in the literature. Accruals were a measure of noncash working capital adjusted for depreciation from the balance sheet (Jones, 1991; Sloan, 1996). Recent papers use any information that they think is relevant to future write-offs that make earnings less persistent to calculate accruals and link it to fundamental growth (Richardson et al., 2005; Sloan, 1996; Zhang, 2007). General findings show that the less the accrual adjustments, the better the earnings persistency and quality (Dechow and Ge, 2006; Dichev and Tang, 2009).

Previous studies show that insiders and managers distort accounting accruals from the true performance for their private benefits (Bartov and Mohanram, 2004; Caton et al., 2011; Teoh et al., 1998). Managers use accruals to make a firm look financially strong temporarily for individual compensations or reputations. A measure of abnormal accruals is used to represent the information quality that comes from earnings. The normal accruals are what investors expect to see from revenue and expense accruals. Any distortions from mismanagement or measurement issues that fluctuate accruals excessively are considered abnormal accruals. Abnormal accruals are suggested to be a measure of earnings mismanagement. Many methods have been developed to accurately measure the correct level of normal accruals. Sales growth and PPE (Plant, properties and equipment) are used to define the accrual process, which is measured by working capital accruals and depreciation by Jones (1991). This model was further developed using past, present and future cash flows to account for the timing of cash recognition (Dechow and Dichev, 2002; Francis et al., 2005). The method used in this paper is a combination of Francis et al. (2005) and Dechow and Dichev (2002). Their models include cash flows of year $t, t-1$ and $t+1$ as well as sales growth to capture firm performance and PPE to reflect depreciation to estimate for the normal accruals. After regressing total accruals to the determining factors, residual is calculated to represent abnormal accruals. Further, the standard deviation of these residuals represents 
how much actual accruals deviate from expected accruals. $\mathrm{Ng}$ (2011) uses a five-year rollover window to calculate the standard deviation of abnormal accruals to represent earnings manipulation. Any deviation from the predicted accruals indicates estimation errors that need to be corrected or reversed in the future, which reduces earnings persistency and quality.
Corporate governance factors

\subsection{Dividends and foreign investors on earnings quality}

Using these measures of earnings management, studies found firm-specific factors that monitor managers and reduce earnings management. The two factors that are relevant for this paper are dividend payout policy and foreign ownership. Prior studies show that dividends limit private control of insiders and reduce agency costs (Jensen, 1986; Pinkowitz et al., 2006). Because dividends deter suboptimal behaviors of managers, it reduces earnings manipulation (Gopalan and Jayaraman, 2012; Leuz et al., 2003). Using multinational data, He et al. (2017) find that earnings management is more prevalent in countries with lower transparency, weaker institutions and lower investor protection but is partially remedied by dividend payouts. In China, dividends are positively associated with "more persistent earnings, higher accrual quality, and greater earnings informativeness" (Deng et al., 2017). Dividend increases help deter earnings management through improving transparency with signaling.

The other factor is monitoring. While dividend payouts reduce agency cost between insiders and outsiders, sophisticated shareholders effectively monitor managers to ensure reported earnings match the fundamentals (Ramalingegowda and $\mathrm{Yu}, 2011$ ). Studies find that foreign institutional investors are well knowledgeable with an immense amount of experience from worldwide and can restrain earnings manipulation (Aggarwal et al., 2011; Becht et al., 2010). Using multinational firm-level data, Lel (2019) finds that the impact of foreign investors on earnings manipulation varies when there are alternative mechanisms that monitor corporate governance. Du et al. (2017) find the presence of monitoring by foreign directors is negatively associated with earnings management. Using Japanese data, Guo et al. (2015) find that earnings management is alleviated with higher foreign ownership.

It is important to study the interactive role of the two factors, dividend and foreign investor, because they are linked. Using Japanese data, studies find that foreign investors lead to higher firm value and more efficient payout decisions (Baba, 2009; Mian and Nagata, 2015). In Korea, foreign investors prefer firms with dividend policies and also exert their rights to demand dividends (Jeon et al., 2011). Kim et al. (2010) use firms with foreign ownership greater than $5 \%$ and find that foreign shares have a significant impact on dividends. Lee and Kim (2018) use the method of Jones (1991) and state that foreign investors demanding higher dividends disrupt earnings quality. This paper finds the interactive role of increasing dividends and foreign ownership in reducing earnings management and provides evidence on whether the two are complements or substitutes.

\section{Data and methodology}

\subsection{Data and key variables}

I obtained financial data of public (listed) Korean firms from KOCOInfo's Total Solution 2000 (TS-2000). A total of 1,851 firms listed under KOSPI and KOSDAQ are included. The sample period spans from 2000 to 2019. A measure of earnings is operating profit over market equity, which is calculated as the price at the end of each fiscal year multiplied by common shares outstanding. Accrual quality is measured using the method of Francis et al. (2005). I follow Dichev and Tang (2009) to estimate total accruals by taking the difference of earnings and 
JDQS 30,1

operating cash flows. Using total accruals, I estimate the following cross-sectional regression for each fiscal year $t$.

$$
\text { TAccr }_{i, t}=\alpha+\beta_{1} \mathrm{CFO}_{i, t-1}+\beta_{2} \mathrm{CFO}_{i, t}+\beta_{3} \mathrm{CFO}_{i, t+1}+\beta_{4} \Delta \operatorname{Rev}_{i, t}+\beta_{5} \mathrm{PPE}_{i, t}+\varepsilon_{i, t}
$$

where $T A c c r_{i, t}$ is total accruals deflated by total assets for firm $i$ in year $t$, CFO is cash flow from operations, $\Delta R e v$ is the change in revenue from the previous year and PPE is plant, property and equipment. CFO is included in the regression to account for the timing of cash flow recognition. Sales growth is for the growth component. For each year, residuals using the coefficients from the cross-sectional regressions are found. These residuals represent abnormal accruals. Then, for each firm in each fiscal year, I calculate the standard deviation of these residuals for fiscal years $t-4$ to $t(\mathrm{Ng}, 2011)$. The fluctuations in abnormal accruals reflect "Accrual quality" and any earnings distortions that indicate earnings management. The accrual component of earnings with lower variance indicates precision in earnings. In other words, lower volatility in accruals implies higher information quality and provides more precise and persistent information regarding earnings. A greater degree of earnings management is indicated by higher variance in abnormal accruals. This measure could be interpreted as how much the managers manipulate earnings (He et al., 2017).

Variables of interest are described here. DiviInc $c_{i, t}$ is an indicator variable that takes on a value of 1 if dividend payout amount increases this year from the previous year and 0 otherwise for firm $i$ in year $t$. The amount of dividend increase is not in this study's interest. Dividend increase is a signal that shows a firm is fundamentally stable. Oppositely, DiviDec $_{i, t}$ is 1 when dividend payout falls from the previous year and 0 otherwise. Dividend decrease is a strong signal that managers avoid. The amount of increase or decrease is not considered in this study. Dividend increase was used for two main reasons. One, as dividend increases and more of the profit is paid out, it would be more difficult for the managers to mess around with the earnings for their personal benefits. Two, foreign investors with their unbiased monitoring could ask for higher dividend payouts so that managers cannot manipulate earnings. Both reasons help explain how dividend increase deters earnings management. Additionally, dividend increase is a signal to outsiders about how the firm will perform in the future (Ham et al., 2020). Instead of dividend yield, which could be altered by annual performance, Ham et al. (2020) use the dividend increase signal. The action of dividend increase conveys positive information about future earnings, indicating better management and governance without earnings manipulation. Thus, a dividend increase is a sign of better governance and transparency.

Foreign ownership share represents the total number of common shares owned by foreign investors over the number of shares outstanding. Size is logarithm of total assets. Earnings are profit scaled to market equity. EarningsManage is the measure of earnings management which is the standard deviation of abnormal accruals. A higher value of EarningsManage from cross-sectional regressions indicates that earnings quality is worsened and suggests that earnings could have been manipulated. Table 1 shows the summary statistics.

\subsection{Methodology and empirical specification}

Univariate analysis is conducted as in Dichev and Tang (2009). Quintile samples are formed on foreign ownership share. The first quintile is $20 \%$ of firms with the lowest foreign ownership share, while the fifth is $20 \%$ with the highest foreign ownership. For each quintile, earnings management is regressed on dividend increase and decrease separately. The coefficients of dividend increase and decrease on earnings manipulation are observed for each quintile. 


\begin{tabular}{lcccc}
\hline Variables & Mean & SD & Min & Max \\
\hline EarningsManage & 6.104 & 6.345 & 0.00133 & 142.6 \\
Divi_Inc & 0.398 & 0.490 & 0 & 1 \\
Divi_Dec & 0.180 & 0.384 & 0 & 1 \\
ForeignShare (\%) & 7.299 & 12.34 & 0 & 92.97 \\
Book to market ratio & 1.488 & 1.511 & 0.102 & 12.81 \\
Size & 18.98 & 1.495 & 15.89 & 24.16 \\
Return & 0.177 & 0.774 & -0.950 & 8.436 \\
Earnings & 0.00574 & 0.0163 & -0.118 & 0.105 \\
Age & 29.40 & 16.74 & 2 & 122
\end{tabular}

Note(s): This table shows the summary statistics of key variables used in this study for all Korean listed firms from 2000 to 2019. There are 1,851 firms with all the variables used in the study. All variables are winsorized at 1 and $99 \%$

Table 1. Summary statistics

To test if earnings management (abnormal accrual) is alleviated by dividend payouts as suggested by Pinkowitz et al. (2006) and foreign share by Jeon et al. (2011) interactively, I set up the following empirical specification:

$$
\begin{aligned}
\text { EarningsManagement }_{i, t}= & \alpha+\beta_{1} \text { Divinc }_{i, t}+\beta_{2} \text { ForShare }_{i, t}+\beta_{3} \text { DiviInc }_{i, t} * \text { ForShare }_{i, t} \\
& +\beta_{4} X_{i, t-1}+\varepsilon_{i, t}
\end{aligned}
$$

where EarningsManagement represents a proxy for earnings management, which is the standard deviation of residuals up to 4 years prior for firm $i$ in year $t$. DiviInc $i, t$ is an indicator variable that takes on a value of 1 if dividend either increased or decreased from the previous year and 0 otherwise. $X_{i, t-1}$ is a vector of control variables that include market to book ratio, size which is the logarithm of total assets, profitability which is return on equity, stock return and age. Fixed-effect panel regression is run to find the relation between dividends and foreign ownership on earnings management.

\section{Results}

This section reports the impact of foreign ownership and dividend increases on earnings management. I find that dividend increases and foreign ownership diminish earnings management. However, as foreign share increases, the impact that dividends have on earnings management decreases. This relationship may be due to foreigners already owning firms with financial stability and no incentive to manage earnings. Another, foreigners could exert ownership rights to monitor and make sure managers serve the shareholders' interests by not manipulating earnings. The results are shown using univariate analysis and panel regression.

\subsection{Univariate analysis}

This method resembles that of Dichev and Tang (2009), where they theorize the relation between earnings persistence and earnings predictability. In this paper, instead of using lagged earnings to predict future earnings, I test if different levels of foreign ownership alter the impact that dividends have on earnings management. Table 2 shows the influence of dividend increase and dividend decrease across quintile by foreign share. Panel A reports the impact of dividend increase on earnings management. Negative coefficients indicate that the standard deviation of abnormal accruals is diminished by dividend increase. This implies 


\section{JDQS 30,1}

Panel A: Dividend increase

Quintile by foreign share

Quintile 1

Quintile 2

Quintile 3

Quintile 4

Quintile 5
Variables

Earnings management

Earnings management

Earnings management

Earnings management

Earnings management
Divi Inc

SE

Observations

$R$-squared

-2.240 ****

$-1.309 * * *$

$-1.276^{* * * *}$

$-0.612^{* * * *}$

$-0.578^{* * * *}$

$(-5.38)$

$(-5.70)$

$(-3.93)$

$(-4.25)$
3,574

4,267

4,629

4,592

4,586
0.0101

0.0067

0.0070

0.0033

0.0039

Panel B: Dividend decrease

Quintile by foreign share

\section{Variables}

Earnings management

Earnings management

Earnings management

Earnings management

Earnings management
Divi Dec

SE

$-1.733^{* * * *}$
$-1.032^{* * * *}$
$-0.502^{* * *}$
$-0.466^{* * *}$
0.114

(-4.34)

(-3.90)

$(-2.03)$

(-2.65)

(0.72)

\begin{tabular}{cc} 
Observations & $R$-squared \\
\hline 3,574 & 0.0052 \\
4,267 & 0.0035 \\
4,629 & 0.0009 \\
4,592 & 0.0015 \\
4,586 & 0.0001
\end{tabular}

Note(s): This table provides estimates from univariate regression of dividend increase and decrease on earnings management. The sample was divided into five by the level of foreign ownership, and regressions were conducted separately. All Korean public firms are included in the sample from 2000 to 2019. Panel A uses dividend increase as the explanatory variable and Panel B uses dividend decrease. Dividend increase and

Table 2.

Univariate analysis decrease are indicator variables. Standard errors from the regressions are reported in parentheses and *** and ** represent statistical significance at the $1 \%$ and $5 \%$ levels, respectively

that a dividend increase reduces earnings management. Baseline results show that there is a strong relationship between the role of dividends in controlling earnings manipulation and foreign share. The coefficient of dividend increase shrinks in magnitude as foreign ownership increases. The role of dividends in suppressing earnings manipulation is not as big when foreign ownership is high. This finding is consistent with what is shown in Figure 1 where the dispersion of earnings management decreases as foreign share increases. Foreigners already monitored when they acquired the voting and control rights to ensure no foul play. Thus, the role of dividends in reducing monitoring and agency costs decreases as foreign investors have higher ownership. In addition, $R$-squared decreases as foreign ownership share increases. This finding indicates that the relationship between dividend increase and earnings management diminishes as foreign ownership increases suggesting a nonlinear relationship with respect to foreign share.

Panel B shows similar results in the univariate analysis, but the significance of dividend decrease is not as strong as dividend increase. Although results in Panel B report a significant linear relationship between dividend decrease and earnings manipulation, especially for lower levels of foreign ownership, this relation disappears when multi-variate regressions are conducted. Thus, dividend increases are explored further.

\subsection{Panel regression analysis}

The results presented in this section controls for firm heterogeneity by using firm characteristics from financial statements to accurately identify the true impact of dividends on earnings management. Multivariate regressions include control variables such as marketto-book ratio, size, earnings, stock return and age. The baseline results on how dividend changes affect earnings management are provided in Table 3.

Columns 1 and 2 are basic OLS regressions without foreign share. Columns 3 and 4 include foreign share as an additional control variable. Columns 5 and 6 include firm and time-fixed effects. While Columns 1, 3 and 5 show that dividend increases help relieve earnings 


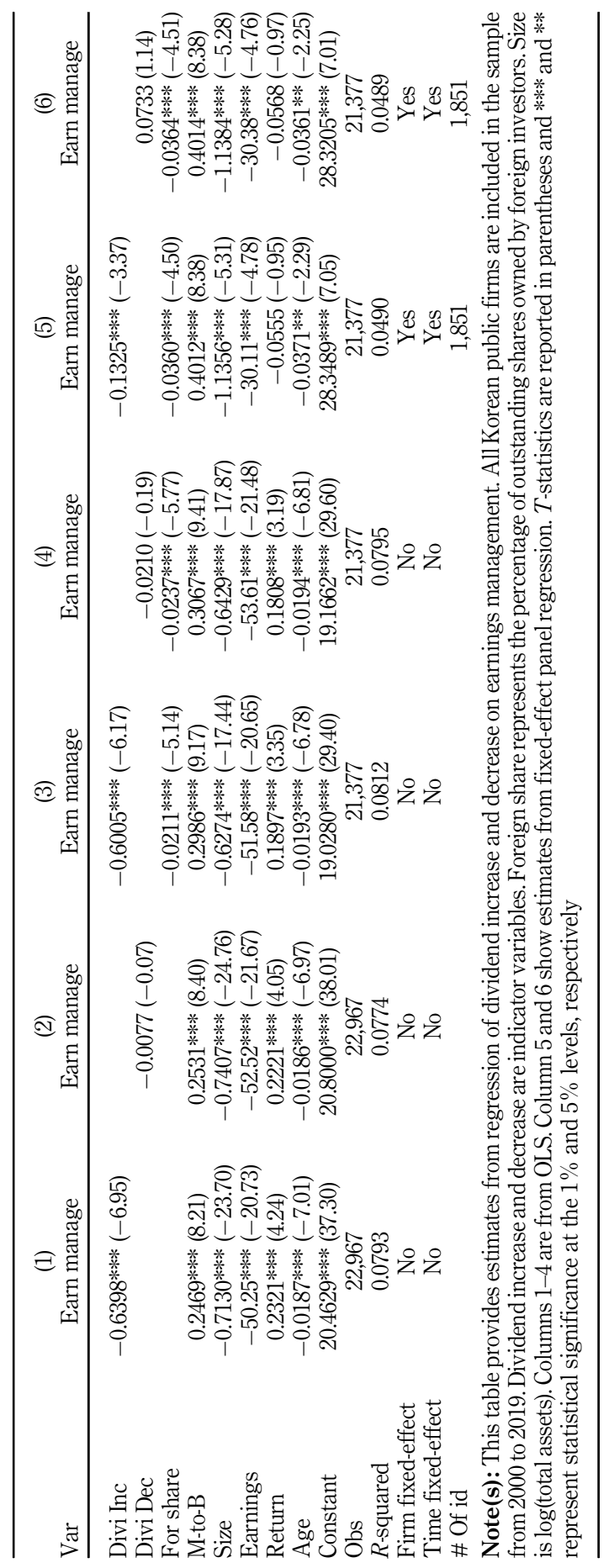

Corporate governance factors

65

Table 3. Baseline regression 
JDQS 30,1

\section{6}

management, Columns 2, 4 and 6 show that dividend decreases after controlling for firm characteristics have no impact. The coefficients for foreign share and dividend increase are negative and statistically significant. Since earnings management is a measure of how volatile the abnormal accruals are, negative signs indicate that dividend increase and foreign share help improve earnings quality. As expected, foreign ownership also mitigates managers' misbehaviors. While Table 3 shows results on how foreign investors and dividend payouts monitor managers, their interactive role is not addressed.

Table 4 address the interaction between dividend increase and foreign ownership by dividing the sample into two by foreign share. One group includes samples with foreign share greater than $5 \%$ while the other consists of firms with less than $5 \%$. In total, $5 \%$ of foreign ownership is considered large enough to influence firm corporate decisions and a voice in annual meetings. A shareholder with more than $3 \%$ of the total outstanding shares is allowed to call for a general meeting. Since there are many institutions that are categorized as foreign investors in Korea, I roughly set the standard at 5\%. I assume that when foreign share increases to above $5 \%$, foreign investors actively monitor to reduce earnings management. The results are shown in Table 4 . Results show that foreign share is only significant in Column 2 where foreign ownership is greater than $5 \%$. The sample was divided using $3 \%$ threshold, and the results were similar. Results from Table 4 suggest that in order for foreign investors to have an effect on earnings management, they should have enough ownership to exercise their rights to monitor the managers. Referring to Figure 1, although a general decreasing pattern of earnings manipulation is observed as foreign share increases, the first $5 \%$ of foreign ownership remains volatile. Evidence from Columns 1 and 2 of Table 4 helps explain in which circumstances foreign investors mitigate earnings manipulation. Table 4 indicates that the level of foreign ownership is essential to play its role in monitoring corporate governance.

To observe the role of a dividend increase and foreign investors in deterring earnings management, Table 5 uses a dummy variable that takes on a value of 1 if the foreign share is greater than $5 \%$ and 0 otherwise. Estimates from Table 5 suggest that having foreign ownership greater than $5 \%$ prevents earnings management. Consistent with the previous

\begin{tabular}{lcc}
\hline & ForShare $<5 \%$ & ForShare $>5 \%$ \\
Variables & EarningsManage & EarningsManage \\
\hline Divi Inc & $-0.1391^{* *}(-2.13)$ & $-0.1394^{*}(-1.96)$ \\
ForShare & $0.0334(0.46)$ & $-0.0283^{* *}(-2.19)$ \\
MtoB & $0.4361^{* * *}(5.30)$ & $0.3515^{* * *}(4.78)$ \\
Size & $-1.3311^{* * *}(-4.21)$ & $-0.9773^{* *}(-2.57)$ \\
Earning & $-32.8658^{* * *}(-5.26)$ & $-18.3166^{*}(-1.98)$ \\
Return & $-0.0001(-0.00)$ & $-0.1399^{*}(-1.81)$ \\
Age & $-0.0584^{*}(-1.90)$ & $-0.0104(-0.21)$ \\
Constant & $32.1000^{* * *}(5.90)$ & $24.6857^{* * *}(3.55)$ \\
Observations & 14,405 & 6,964 \\
$R$-squared & 0.0487 & 0.0689 \\
Firm FE & Yes & Yes \\
Time FE & Yes & Yes
\end{tabular}

Table 4.

Regression by foreign share greater or less than $5 \%$

Note(s): This table provides estimates from regression of dividend increase and foreign share on earnings management. All Korean public firms are included in the sample from 2000 to 2019. Foreign share represents the percentage of outstanding shares owned by foreign investors. Column 1 shows coefficients from the estimation with firms that have foreign share less than $5 \%$. Column 2 reports results with firms that have a foreign share greater than $5 \%$. T-statistics are reported in parentheses and ***, ** and * represent statistical significance at the 1,5 and $10 \%$ levels, respectively 


\begin{tabular}{|c|c|c|c|}
\hline Variables & $\begin{array}{c}(1) \\
\text { EarningsManage }\end{array}$ & $\begin{array}{c}(2) \\
\text { EarningsManage }\end{array}$ & $\begin{array}{l}\text { Corporate } \\
\text { governance }\end{array}$ \\
\hline Divi_Inc & $-0.1441 * *(-2.81)$ & $-0.2663 * * *(-3.38)$ & \\
\hline For_5percent & $-0.4045 * * *(-3.06)$ & $-0.4960 * * *(-3.16)$ & \\
\hline For_5percent*Divi_Inc & & $0.2783 * *(2.26)$ & \\
\hline Constant & $28.0329 * * * *(7.32)$ & $28.0824 * * *(7.34)$ & \\
\hline Observations & 22,967 & 22,967 & 67 \\
\hline$R$-squared & 0.0490 & 0.0491 & \\
\hline Controls & Yes & Yes & \\
\hline Firm FE & Yes & Yes & \\
\hline Time FE & Yes & Yes & $\begin{array}{l}\text { Table } 5 . \\
\text { Regression with the }\end{array}$ \\
\hline \multicolumn{3}{|c|}{$\begin{array}{l}\text { Note(s): This table presents the results from the fixed-effect panel regression with a dummy variable that is } 1 \\
\text { for firms with a foreign share greater than } 5 \% \text { and } 0 \text { otherwise. T-statistics are reported in parentheses, and *** } \\
\text { and ** represent statistical significance at the } 1 \% \text { and } 5 \% \text { levels, respectively }\end{array}$} & $\begin{array}{l}\text { indicator variable for } \\
\text { firms with a foreign } \\
\text { share greater than } 5 \%\end{array}$ \\
\hline
\end{tabular}

results, higher foreign ownership prevents earnings management but serves to be substitutes with dividend increases. That is indicated by the positive coefficient of the interaction term.

Although Lee and Kim (2018) already showed that foreign share and dividends interactively affect earnings management using the method of Jones (1991), I contribute by providing a new interpretation of the relationship between the two factors. I argue that foreign investors and dividend payouts deter earnings management through different channels. While the former scrutinizes and monitors for better performance, the latter signals future growth and better governance through enhancing transparency. Both channels are important for preventing earnings management. My findings suggest that both the signaling and monitoring prevent managers from manipulating earnings for private benefits but those two serve to be substitutes. This is additionally shown using the foreign ownership level in Table 6.

In Table 6, I test if foreign investors and dividend increases interactively reduce earnings management by utilizing the interaction term. In Column 2 of Table 6 , dividend decrease is

\begin{tabular}{lccc}
\hline & $(1)$ & $(2)$ & $(3)$ \\
Variables & EarningsManage & EarningsManage & EarningsManage \\
\hline Divi Inc & $-0.2114^{* * *}(-3.91)$ & & $-0.2729^{* * *}(-2.71)$ \\
Divi Inc * For & $0.0089^{*}(1.89)$ & & $0.0187^{* * *}(2.11)$ \\
Divi Dec & & $0.0229(0.29)$ & $-0.1250(-1.01)$ \\
Divi Dec * For & & $0.0061(0.91)$ & $0.0179(1.54)$ \\
For share & $-0.0395^{* * *}(-5.09)$ & $-0.0377^{* * *}(-4.27)$ & $-0.0471^{* * * *}(-4.38)$ \\
Constant & $28.3721^{* * *}(7.06)$ & $28.3316^{* * *}(6.99)$ & $28.4365^{* * *}(7.01)$ \\
Observations & 21,377 & 21,377 & 21,377 \\
$R$-squared & 0.0491 & 0.0490 & 0.0493 \\
Control & Yes & Yes & Yes \\
Firm FE & Yes & Yes & Yes \\
Time FE & Yes & Yes &
\end{tabular}

Note(s): This table reports estimates from regressing earnings management on dividend increase and foreign share interactively. All Korean public firms are included in the sample from 2000 to 2019. Foreign share represents the percentage of outstanding shares owned by foreign investors. Dividend increase is an indicator variable that is 1 if dividend increased from the previous year and 0 if otherwise. Column 1 shows coefficients from the estimation with dividend increases. Column 2 shows coefficients from the estimation with dividend decreases. Column 3 includes all the interactive variables. $T$-statistics are reported in parentheses and ***, ** and $*$ represent statistical significance at the 1,5 , and $10 \%$ levels, respectively

Table 6 .

Regression with interaction terms using foreign ownership level 
JDQS 30,1

\section{8}

Table 7.

With the change in ownership level of foreign and domestic institutional investors insignificant to earnings management as in Table 3. Columns 1 and 3 of Table 6 show that dividend increases and foreign investors improve earnings quality. However, those two act as substitutes where an increase in one reduces the impact of another. When foreign share increases, the impact that dividend increase has on earnings management is reduced. This could be explained by the monitoring of foreign investors where dividend remains important in reducing agency costs, but the influence is weakened. Notably, foreign ownership does not fully eradicate earnings management because it may still exist even when a firm is wholly owned by foreign investors. The internal decision to pay out dividends is useful in enhancing earnings quality even when a firm has high foreign share.

To strengthen the argument that foreign investor monitoring and dividend increases are substitutes in preventing earnings management, I additionally use domestic institutional investors. Lee and Kim (2018) argued that foreign investors request higher dividends and thus causing firms to manipulate earnings to meet their demands. Then, if that were true, domestic institutional investors who also monitor but have different preferences for dividends should show different results. However, Table 7 shows that even with the data of domestic institutional investors, the results are similar. Jeon et al. (2011) find that foreign investors exhibit control to demand higher payouts, but highly unlikely at the cost of losing earnings quality. Table 7 suggests that monitoring of institutional investors both by domestic and foreign deter earnings management but are substitutes with signaling with payout policies. Because the data on domestic institutional investor ownership level has many missing values, I used the net purchase data. Insti_buy ${ }_{i, t}$ takes on a value of 1 if domestic institutional ownership increased from the previous year, indicated by the positive net purchase of stock transactions of firm $i$ in year $t$ and 0 otherwise. Similarly, I find For_buy $_{i, t}$ using the stock net purchase of foreign investors. Column (1) of Table 7 uses foreign net purchase data. While the signs of coefficients are similar, they lack statistical significance. Estimates from Column (1) of Table 7 suggest that the change in foreign share is not important, but the level is. This is consistent with the results provided in Table 5 . Column (2) of Table 7 provides evidence that domestic institutional investors also monitor for better earnings reporting. Similar to foreign investors, the positive coefficient of the interaction term between monitoring by domestic institutional investors and signaling through dividend

\begin{tabular}{lcc}
\hline & $(1)$ & $(2)$ \\
Variables & EarningsManage & EarningsManage \\
\hline Divi_Inc & $-0.2313^{* * *}(-3.08)$ & $-0.2973^{* * * *}(-3.97)$ \\
For_buy & $-0.0589(-0.78)$ & \\
Divi_Inc*For_buy & $0.1581(1.40)$ & $-0.2515^{* * * *}(-2.85)$ \\
Insti_buy & & $0.3332^{*}(2.01)$ \\
Divi_Inc* Insti_buy & $28.9454^{* * *}(7.10)$ & $29.0702^{* * *}(7.15)$ \\
Constant & 22,546 & 22,546 \\
Observations & 0.0489 & 0.0493 \\
$R$-squared & Yes & Yes \\
Controls & Yes & Yes \\
Firm FE & Yes & Yes \\
Time FE & Yes
\end{tabular}

Note(s): This table reports estimates from regressing earnings management on dividend increase and dummy variables that indicate increase in ownership of foreign and domestic institutional investors. For_buy takes on a value of 1 if net purchase by foreign investors is positive for firm $i$, and 0 otherwise. For_buy being 1 indicates that foreign ownership increased from the previous year. Similarly, Insti_buy is constructed. Column 1 shows coefficients from the estimation with foreign ownership change. Column 2 shows coefficients from the estimation with domestic institutional ownership change. $T$-statistics are reported in parentheses and *** and * represent statistical significance at the $1 \%$ and $10 \%$ levels, respectively 
increase indicates that the two factors are substitutes. It is unreasonable to interpret the positive coefficient of the interaction term as foreign investors encouraging earnings management for higher dividend payouts.

\subsection{Alternative measure of earnings management}

While accruals are commonly used to quantify a measure of earnings management, some studies simply use the volatility of earnings (Dichev and Tang, 2009; Ng, 2011). The volatility of earnings is also known as earnings precision. I take the recent five years of earnings and calculate the standard deviation to represent earnings volatility. Higher volatility indicates that earnings reported are less precise due to mismanagement of insiders. The control variables included in the regressions are analogous to previous results.

The findings from Table 8 resemble those of Table 6 where dividend increases and foreign share both decrease the volatility of earnings. Consistently, the interaction term of foreign share and dividend increase is positive in Column (4). This result indicates that an increase in foreign ownership reduces the role of a dividend increase in decreasing earnings volatility and, thus, earnings quality. The results from Table 8 consistently support the claim that foreign share and dividend increase both are significant in reducing earnings management, but they act as substitutes.

\subsection{Dividend status}

Many studies look at dividend payout status or dividend yield instead of dividend increases to measure better transparency when observing its role in deterring earnings management (Deng et al., 2017; Graham and Kumar, 2006; He et al., 2017; Lee and Kim, 2018). However, this paper focuses on signals given by dividend increases as it conveys information about future performances (Ham et al., 2020) and better governance. To ensure the results in this paper are consistent with the previous findings, I use the dividend status indicator in Table 9. Dividend

\begin{tabular}{|c|c|c|c|c|}
\hline Variables & $\begin{array}{c}(1) \\
\text { Vol (earning) }\end{array}$ & $\begin{array}{c}(2) \\
\text { Vol (earning) }\end{array}$ & $\begin{array}{c}(3) \\
\text { Vol (earning) }\end{array}$ & $\begin{array}{c}(4) \\
\text { Vol (earning) }\end{array}$ \\
\hline Divi Inc & $-0.249 * * *(-4.62)$ & & $-0.244^{* * * *}(-4.56)$ & $-0.365^{* * *}(-3.37)$ \\
\hline ForShare & & $-0.025^{* *}(-2.66)$ & $-0.024^{* *}(-2.62)$ & $-0.029 * *(-2.70)$ \\
\hline Divi Inc*ForShare & & & & $0.014 *(1.96)$ \\
\hline MtoB & $-0.307 * * *(-4.63)$ & $-0.314 * * *(-4.60)$ & $-0.315^{* * *}(-4.58)$ & $-0.315^{* * *}(-4.58)$ \\
\hline Size & $-0.242(-1.23)$ & $-0.258(-1.14)$ & $-0.265(-1.18)$ & $-0.267(-1.18)$ \\
\hline Earning & $-0.782(-0.10)$ & $-0.601(-0.07)$ & $-0.396(-0.05)$ & $-0.313(-0.04)$ \\
\hline Return & $0.623 * * *(3.13)$ & $0.634^{* * *}(3.15)$ & $0.638 * * *(3.17)$ & $0.636 * * *(3.17)$ \\
\hline Age & $-0.204 * * *(-6.86)$ & $-0.204 * * *(-6.31)$ & -0.206 **** $(-6.33)$ & $-0.205^{* * * *}(-6.32)$ \\
\hline Constant & 13.347 *** (3.50) & $13.756 * * *(3.15)$ & $14.015^{* * * *}(3.22)$ & $14.064 * * *(3.22)$ \\
\hline Observations & 23,778 & 22,110 & 22,110 & 22,110 \\
\hline$R$-squared & 0.0408 & 0.0404 & 0.0408 & 0.0411 \\
\hline Firm fixed-effect & Yes & Yes & Yes & Yes \\
\hline Time fixed-effect & Yes & Yes & Yes & Yes \\
\hline
\end{tabular}

Note(s): This table reports estimates from regressing an alternative measure of earnings management instead of abnormal accruals: the volatility of earnings on dividend increase and foreign share interactively. All Korean public firms are included in the sample from 2000 to 2019. Foreign share represents the percentage of outstanding shares owned by foreign investors. Dividend increase is an indicator variable that is 1 if dividend increased from the previous year and 0 if otherwise. Column 1 shows coefficients from the estimation with dividend increases. Column 2 shows coefficients from the estimation with dividend decreases. Column 3 includes all the interactive variables. $T$-statistics are reported in parentheses and ***, ** and * represent statistical significance at the 1,5 and $10 \%$ levels, respectively

$$
\text { but they act as substitutes. }
$$

\section{Corporate governance factors}




\begin{tabular}{|c|c|c|c|}
\hline 30,1 & Variables & $\stackrel{(1)}{\text { EarningsManage }}$ & $\begin{array}{c}(2) \\
\text { EarningsManage }\end{array}$ \\
\hline 70 & $\begin{array}{l}\text { Divi_Dum } \\
\text { Forshare } \\
\text { Divi_Dum*Forshare } \\
\text { MtoB } \\
\text { Size } \\
\text { Earning }\end{array}$ & $\begin{array}{c}-0.3974 * *(-2.12) \\
-0.0350 * * *(-4.60) \\
0.4007 * * *(8.38) \\
-1.1214^{* * * *}(-5.36) \\
-290508 * * *(-476)\end{array}$ & $\begin{array}{c}-0.5961 * * *(-3.00) \\
-0.0613^{* * * *}(-4.14) \\
0.0387 * *(2.42) \\
0.4006 * * *(8.36) \\
-1.1331 * * *(-5.35) \\
-28.8287 * * *(-479)\end{array}$ \\
\hline & $\begin{array}{l}\text { Return } \\
\text { Constant } \\
\text { Observations } \\
R \text {-squared } \\
\text { Firm fixed-effect } \\
\text { Time fixed-effect }\end{array}$ & $\begin{array}{c}-0.0529(-0.91) \\
28.2646^{* * *}(7.11) \\
21,377 \\
0.0495 \\
\text { Yes } \\
\text { Yes }\end{array}$ & $\begin{array}{c}-0.0548(-0.96) \\
28.5164 * * *(7.10) \\
21,377 \\
0.0503 \\
\text { Yes } \\
\text { Yes }\end{array}$ \\
\hline $\begin{array}{l}\text { Table } 9 . \\
\text { Dividend status }\end{array}$ & \multicolumn{3}{|c|}{$\begin{array}{l}\text { Note(s): This table reports the results from fixed-effect panel regression with dividend status. Divi_Dum is an } \\
\text { indicator variable that is } 1 \text { if a firm } i \text { pays dividends in year } t \text {, and } 0 \text { otherwise. Column } 1 \text { shows coefficients from } \\
\text { the estimation without the interaction term. Column } 2 \text { shows the results with the interaction term, which shows } \\
\text { a positive sign. } T \text {-statistics are reported in parentheses and } * * * \text { and } * * \text { represent statistical significance at the } \\
1 \% \text { and } 5 \% \text { levels, respectively }\end{array}$} \\
\hline
\end{tabular}

status is an essential characteristic for investors as it provides information about stock prices and how a firm manages its profits. Paying out dividends decreases agency costs and helps prevent earnings management.

Estimates from Column (1) of Table 9 are consistent with prior research studies on whether a firm pays dividends or not affects earnings management. In addition, the interaction term in Column (2) between foreign ownership share and dividend status is positively associated with earnings management. As before, this result suggests two possible interpretations. Foreign investors play less of a role in deterring earnings management because dividend payouts already mitigate the issue. Another, dividend payout status has more negligible effect on earnings quality because foreign investors are already actively monitoring for better corporate governance. The results indicate that dividend payouts and foreign investor monitoring diminish each other's effect in deterring earnings management.

\section{Conclusion}

This study examines how foreign investors and dividend payouts interactively affect earnings quality by preventing manager misbehaviors. I find that these two inhibiting factors of earnings management are substitutes where an increase in one reduces the impact of another. As foreign share increases, earnings management decreases. The role of foreign investors is greater when their ownership exceeds $5 \%$. Additionally, domestic institutional investors played a similar role in deterring earnings management. Domestic institutional investors also monitor to improve corporate governance, which also enhances earnings quality. Generally, this study contributes to the literature by finding that monitoring by sophisticated investors and improving transparency by dividend increases are substitutes in deterring earnings management.

While it may be important to distinguish the effectiveness of foreign and domestic institutional investors, the ownership data for institutional investors is relatively incomplete. Such limitations could be eliminated as the data availability increase. Also, future studies could explore how other corporate governance factors, such as auditing quality, outside 
directors and family ownership, interactively reduce earnings management with the factors mentioned in this study. Other measures of earnings quality, such as CAR (cumulative abnormal returns) around earnings announcement, can be used to investigate further. This method assumes that investors react to abnormal reportings of earnings that deviate from the fundamentals. Lastly, the interactive role of dividends and foreign ownership on earnings persistence could also be explored.

\section{Corporate governance factors}

\section{References}

Aggarwal, R., Erel, I., Ferreira, M. and Matos, P. (2011), "Does governance travel around the world? Evidence from institutional investors", Journal of Financial Economics, Vol. 100, pp. 154-181.

Baba, N. (2009), "Increased presence of foreign investors and dividend policy of Japanese firms", Pacific-Basin Finance Journal, Vol. 17, pp. 163-174.

Bartov, E. and Mohanram, P. (2004), "Private information, earnings manipulations, and executive stock-option exercises", The Accounting Review, Vol. 79, pp. 889-920.

Becht, M., Franks, J., Mayer, C. and Rossi, S. (2010), "Returns to shareholder activism: evidence from a clinical study of the Hermes UK focus fund", Review of Financial Studies, Vol. 23, pp. 3093-3129.

Caton, G.L., Chiyachantana, C.N., Chua, C.-T. and Goh, J. (2011), "Earnings management surrounding seasoned bond offerings: do managers mislead ratings agencies and the bond market?", Journal of Financial and Quantitative Analysis, Vol. 46, pp. 687-708.

Chen, X., Harford, J. and Li, K. (2007), "Monitoring: which institutions matter?", Journal of Financial Economics, Vol. 86, pp. 279-305.

Dechow, P.M. and Dichev, I.D. (2002), "The quality of accruals and earnings: the role of accrual estimation errors", The Accounting Review, Vol. 77, pp. 35-59.

Dechow, P. and Ge, W. (2006), "The persistence of earnings and cash flows and the role of special items: implications for the accrual anomaly", Review of Accounting Studies, Vol. 11, pp. 253-296.

Dechow, P., Ge, W. and Schrand, C. (2010), "Understanding earnings quality: a review of the proxies, their determinants and their consequences", Journal of Accounting and Economics, Vol. 50, pp. 344-401.

Deng, L., Li, S. and Liao, M. (2017), "Dividends and earnings quality: evidence from China", International Review of Economics and Finance, Vol. 48, pp. 255-268.

Dichev, I.D. and Tang, V.W. (2009), "Earnings volatility and earnings predictability", Journal of Accounting and Economics, Vol. 47, pp. 160-181.

Du, X., Jian, W. and Lai, S. (2017), "Do foreign directors mitigate earnings management? Evidence from China", The International Journal of Accounting, Vol. 52, pp. 142-177.

Ferreira, M.A. and Matos, P. (2008), "The colors of investors' money: the role of institutional investors around the world", Journal of Financial Economics, Vol. 88, pp. 499-533.

Francis, J., Lafond, R., Olsson, P. and Schipper, K. (2005), “The market pricing of accruals quality", Journal of Accounting and Economics, Vol. 39, pp. 295-327.

Gopalan, R. and Jayaraman, S. (2012), "Private control benefits and earnings management: evidence from insider controlled firms", Journal of Accounting Research, Vol. 50, pp. 117-157.

Graham, J.R. and Kumar, A. (2006), "Do dividend clienteles exist? Evidence on dividend preferences of retail investors", The Journal of Finance, Vol. 61, pp. 1305-1336.

Guo, J., Huang, P., Zhang, Y. and Zhou, N. (2015), "Foreign ownership and real earnings management: evidence from Japan", Journal of International Accounting Research, Vol. 14, pp. 185-213.

Ham, C.G., Kaplan, Z.R. and Leary, M.T. (2020), "Do dividends convey information about future earnings?”, Journal of Financial Economics, Vol. 136, pp. 547-570. 
JDQS 30,1

He, W., Ng, L., Zaiats, N. and Zhang, B. (2017), "Dividend policy and earnings management across countries", Journal of Corporate Finance, Vol. 42, pp. 267-286.

Jensen, M.C. (1986), “Agency costs of free cash flow, corporate finance, and takeovers”, The American Economic Review, Vol. 76, pp. 323-329.

Jeon, J.Q., Lee, C. and Moffett, C.M. (2011), "Effects of foreign ownership on payout policy: evidence from the Korean market", Journal of Financial Markets, Vol. 14, pp. 344-375.

Jones, J.J. (1991), "Earnings management during import relief investigations", Journal of Accounting Research, Vol. 29, pp. 193-228.

Kim, S., Sul, W. and Kang, S. (2010), "Impact of foreign institutional investors on dividend policy in Korea: a stock market perspective", Journal of Financial Management and Analysis, Vol. 23, pp. 10-26.

Lee, S.H. and Kim, M.T. (2018), "A study on dividend pressure by foreign investors and earnings management", Korean Journal of Accounting Research, Vol. 23, pp. 35-56.

Lel, U. (2019), "The role of foreign institutional investors in restraining earnings management activities across countries", Journal of International Business Studies, Vol. 50, pp. 895-922.

Leuz, C., Nanda, D. and Wysocki, P.D. (2003), "Earnings management and investor protection: an international comparison”, Journal of Financial Economics, Vol. 69, pp. 505-527.

Mian, R. and Nagata, K. (2015), "Foreign institutional ownership and the valuation effect of investment and payout decisions", Journal of Finance and Economics, Vol. 3, pp. 97-104.

$\mathrm{Ng}$, J. (2011), "The effect of information quality on liquidity risk", Journal of Accounting and Economics, Vol. 52, pp. 126-143.

Pinkowitz, L., Stulz, R. and Williamson, R. (2006), "Does the contribution of corporate cash holdings and dividends to firm value depend on governance? A cross-country analysis", The Journal of Finance, Vol. 61, pp. 2725-2751.

Ramalingegowda, S. and Yu, Y. (2011), "Institutional ownership and conservatism", Journal of Accounting and Economics, Vol. 53, pp. 98-114.

Richardson, S.A., Sloan, R.G., Soliman, M.T. and Tuna, İ. (2005), "Accrual reliability, earnings persistence and stock prices”, Journal of Accounting and Economics, Vol. 39, pp. 437-485.

Sloan, R.G. (1996), "Do stock prices fully reflect information in accruals and cash flows about future earnings?”, The Accounting Review, Vol. 71, pp. 289-315.

Teoh, S.H., Welch, I. and Wong, T.J. (1998), "Earnings management and the long-run market performance of initial public offerings", The Journal of Finance, Vol. 53, pp. 1935-1974.

Zhang, X.F. (2007), "Accruals, investment, and the accrual anomaly", The Accounting Review, Vol. 82, pp. 1333-1363.

\section{Corresponding author}

Jong Hwa Lee can be contacted at: jhlee@donga.ac.kr

For instructions on how to order reprints of this article, please visit our website:

www.emeraldgrouppublishing.com/licensing/reprints.htm

Or contact us for further details: permissions@emeraldinsight.com 